\title{
Como a recepção da filosofia interfere no seu modo de ensino? Uma discussão a partir de alguns interlocutores de Sócrates
}

Vinicius B. Vicenzi ${ }^{\mathrm{i}}$

\section{Resumo}

Este artigo apresenta o diálogo Górgias de Platão como um cenário interessante por onde pensar a relação do ensino de filosofia com interlocutores não-filósofos, buscando pontos de encontro entre a cena antiga e a cena de hoje. Os três personagens do diálogo platônico são pensados a partir de afetos que os caracterizam na relação com o ensino socrático e a intenção é ver em que medida o ensino de filosofia se modifica de acordo com esses afetos.

Palavras-chave: ensino, filosofia, afetos, Platão, Górgias.

\section{Introdução}

Muito se ouve em filosofia, e não seria diferentemente no que convencionamos chamar de "ensino de filosofia”, sobre a sua defesa, apesar de o termo aqui já ser motivo de polêmica. Filósofos e professores de filosofia não se sentem confortáveis em se autoafirmarem “defensores” da filosofia. Para além da defesa e da acusação, próprias do tribunal e, portanto, de um discurso sofístico, a filosofia não seria um assunto que merece esse tipo de relação consigo. Não haveria do que se defender porque aqueles que a acusam não teriam razão de fazê-lo, não compreendem bem o que seja a filosofia e, portanto, frente àquilo de que a acusam sequer haveria necessidade de se contrapor. Bastaria, ao invés de defendê-la, promovê-la, praticá-la. Nesta acepção, bastaria também ao ensino da filosofia um discurso de promoção da disciplina, de promoção da prática filosófica.

Gostaria, ao contrário, de tomar a sério aquilo que falam os que à filosofia se opõem, de olhar para aqueles que "recebem” a filosofia e, não simplesmente, para aqueles que a “transmitem”. Não porque estejam necessariamente certos em suas críticas, mas simplesmente porque penso ser necessário ao diálogo que nós, seus professores, ouçamos o que têm a dizer não só os que se solidarizam com o nosso discurso, mas também todos os outros. Em última instância, parece estar em jogo aqui uma necessidade do ensino da filosofia ouvir todos os seus interlocutores, aqueles que são mais simpáticos a esse saber e também aqueles mais hostis. Essa exigência se faz ainda mais urgente se pensarmos o contexto no qual o ensino de filosofia se vê inserido. Ao invés de um ensino elitizado, a realidade da filosofia hoje, ao ser 
apresentada em nossas escolas de forma obrigatória, é ser direcionada a todos que ali estão, solidários ou hostis, independentemente. Urge então pensar o que fazer com essa constatação. Nem tanto para dar uma resposta, uma solução que resolva esse impasse da relação da filosofia com o outro, porque talvez esse seja justamente um elemento constituinte do ensino da filosofia, mas para que seja possível nessa relação com o outro não anteciparmos aqueles que incluiremos e aqueles que excluiremos de uma relação com a filosofia.

Um lugar particularmente interessante para ver a filosofia tomando a sério as intervenções de seus interlocutores resistentes são os Diálogos de Platão, em especial aqueles em que sofistas e oradores aparecem, como o Górgias. Ao contrário do que muitos pensam, não basta simplesmente apresentar a filosofia para que ela seja aprendida. Nem mesmo Sócrates assim agia. Os seus Diálogos revelam muito mais do que teorias ou ideias. Revelam um modo de agir, um método talvez, que pensa a filosofia em relação com o outro. Se assumimos com certa rapidez a vitória da filosofia sobre o seu outro, no caso a sofística e, por isso, vemos sem sentido, quase como perda de tempo, dialogarmos com discursos que se valem de subprodutos dessas, como a política, a propaganda, etc., seja em debates educacionais ou filosóficos, nem por isso me parece tranquilo e inteligente pensarmos que o outro da filosofia desapareceu, sumiu, morreu. Enterrar um fantasma, ou pior, decretar a morte de um vivo é tornar-se cego, ou melhor, fingir não ver aquilo que se apresenta. E nós, professores de filosofia, talvez nos tenhamos acostumado a ver esses fantasmas todo dia, a cada aula. Nossos alunos são a fiel assumpção de que o outro está sempre presente. Tentamos enterrá-lo muitas vezes, desconsideramos suas intervenções, colocamos no rol das “normalidades”, como uma questão de gosto, afinal, nem todos vão gostar de filosofia, não é mesmo? E seguimos vivendo, nós e os fantasmas. Num mesmo real que, obviamente, não compartilhamos. Com isso não estou a dizer que alunos e sofistas partilhem das mesmas ideias, ainda que elas possam alguma vez coincidir. Essa aproximação serve muito mais para que a filosofia e seu ensino não se arroguem de uma presunção que não se constata, à medida que toda vez é um outro que conosco vem conversar. A hostilidade ou resistência de nossos alunos, para além de uma deficiência, de aprendizagem, de "bagagem” escolar, de “motivação política”, etc., apenas revela que a filosofia deve se preocupar com esse outro, não simplesmente para convencê-lo, o que talvez, paradoxalmente, possa ser o caso, mas num primeiro momento simplesmente como esforço de compreensão, de comunicação. Para não sobrarmos no mundo, para não nos isolarmos em castelos de marfim ou em ilhas ambulantes, penso que vale revisitarmos o universo erístico dos Diálogos. 


\section{Górgias: o aluno solidário?}

O diálogo se inicia com Sócrates e seu amigo Querefonte chegando atrasados a uma festa na casa de Cálicles, onde Górgias se hospedara e onde há pouco havia terminado um belo discurso. Górgias é chamado para que Sócrates lhe interrogue sobre “a virtude própria de sua arte, e [sobre] que arte é essa que professa e que ensina” (447c), mas após poucas perguntas de Querefonte, Polo, amigo de Górgias, pede para que as perguntas lhe sejam dirigidas, pois Górgias estaria cansado. Sócrates, incomodado com o rumo das perguntas e respostas dos dois novatos, Querefonte e Polo, que não respondem o que seria a arte de Górgias mas estão a qualificar se essa arte é bela ou não, assume o diálogo e passa a interrogar diretamente Górgias. O orador havia defendido que não se pode julgar a disciplina pelo seu uso benéfico ou maléfico, mas agora, a partir de uma série de argumentos por analogia entre ser e aprender, Górgias se vê forçado a admitir que quem aprendeu justiça será justo e que o orador, que devia aprender exatamente isso, será também justo, com o quê não poderia haver uso mal da retórica. Bom, não entrando aqui nos detalhes da argumentação, o que não é objeto aqui, mas simplesmente no fato de que o interlocutor de Sócrates, no caso Górgias, foi solidário ao discurso do filósofo e, com isso, se contradisse, abrem-se algumas perguntas que os interlocutores posteriores talvez nos ajudem a responder. Primeiro, como é possível a alguém que dizia que "há muitos anos ninguém me faz uma pergunta que me apanhe desprevenido” (448a) caia em contradição assim, com tamanha tranquilidade? É isso fruto da habilidade socrática ou da solidariedade de Górgias, ou ainda um efeito das duas coisas? Haveria alguma relação entre o fato de Górgias estar cansado com o fato de ter sido apanhado desprevenido? Ou como tentarão defender seus amigos mais adiante, Górgias simplesmente fez o jogo de Sócrates, mas em nenhum momento assumiu verdadeiramente aquilo que dizia? Se esse último questionamento vale, então poderíamos pensar no que significa ser solidário ao discurso da filosofia. Todo aluno que aparentemente faz o percurso da filosofia filosofa verdadeiramente? Ou poderia acontecer de alunos responderem, como Górgias, aquilo que nós, professores de filosofia, queremos ouvir, mas nem por isso estejam significando ou vivenciando aquele “aprendizado filosófico”? Se há um espaço na linguagem para que isso ocorra, um lugar do explícito que não necessariamente reflete uma intenção daquele que fala, então é preciso duvidar inclusive dos “solidários” à filosofia. Nosso problema, então, de perceber a relação da filosofia com o outro, assume assim uma nova dimensão, a de pensar não só nos interlocutores hostis mas também nos simpáticos à filosofia e na qualidade dessa simpatia. Se é verdade o que defende Polo, de que Górgias "se 
envergonhou de não concordar com a tua [de Sócrates] afirmação” (461c), então Górgias pode assumir aqui, quiçá, o caráter da primeira fala pedagogizada da história, ou seja, do primeiro aluno que entendeu o processo de poder entre mestre e aluno e, convencido disso, elaborou e proferiu uma fala própria dessa relação, uma fala mantenedora da ordem dessa estrutura, mas totalmente desprovida de sentido próprio.

Outro aspecto relevante dessa relação "pedagógica” de Sócrates e Górgias é que nos mostra que a contradição, ápice da maiêutica socrática e, portanto, ápice da filosofia, não coage em absoluto à posição sofística, como pretendia Platão. A menos, não no nível dos sujeitos, isto é, não no nível daqueles que se dizem sofistas. Se a contradição mostra aos leitores, à tradição leitora da filosofia a fragilidade da sofística, e em certa medida, talvez, sua derrota histórica, para os sofistas o enredo em uma contradição era apenas mais um fato no mundo, algo sem grandes consequências para suas trajetórias.

\section{Polo: o aluno resistente}

Polo inicia sua participação no diálogo por meio de um ato em defesa de Górgias. Ao defender esse outro “aluno”, Polo se mostra como o resistente a Sócrates.

"Polo: julgas que, lá porque Górgias se envergonhou de não concordar com a tua afirmação de que o orador conhece o justo, o belo e o bom e está em condições de ensinar estas coisas a quem o procura sem as ter aprendido antes, donde resultou talvez uma certa contradição nas suas palavras - coisa que tu muito aprecias, ao arrastar pessoas a questões deste gênero... Claro que ninguém vai dizer que não conhece o que é justo e que não é capaz de o ensinar aos outros!” (461b-c)

Sócrates não passa em vão por essa colocação de Polo. Como pode a contradição não encerrar o diálogo? Não ensinar, portanto? O objetivo último da educação filosófica, ou seja, mostrar ao seu interlocutor a sua ignorância não é determinante para a modificação deste sujeito? Se Platão e a filosofia posterior podem dormir em paz frente à objeção de Polo, frente a um certo “cinismo” sofístico, Sócrates, curiosamente, parece não poder. E, lançando mão de uma de suas ferramentas retóricas mais hábeis, a ironia, reinsere o seu interlocutor resistente no caminho do diálogo consigo.

“Sócrates: Meu caro Polo, é exatamente para isto que nós devemos querer os amigos e os 
filhos, para, quando, já velhos, nos acontece de dar algum passo em falso, corrigirem nossos atos e as nossas palavras. Agora, se porventura eu e Górgias erramos nos nossos raciocínios, estás tu presente para nos corrigir.” (461d)

No entanto, o filósofo lhe faz uma exigência: que refreie sua tendência para longos discursos, pois assim, se porventura tivesse de deixar o recinto, não teria a infelicidade de perder de ouvir suas palavras. Uma exigência no mínimo curiosa esta de pedir que o interlocutor fale de acordo com uma medida, de acordo com um metron da sua filosofia. A filosofia como “medida de todos os discursos”? O artifício socrático que recoloca Polo no diálogo é extremamente retórico, persuasivo, pois o força a aderir uma tradição de fala que não é sua. Sócrates, curiosamente no entanto, oferta a seu interlocutor, como num jogo de tabuleiro, dois peões, o de perguntar e o de responder e pede que escolha. Polo, de forma sagaz, escolhe o papel de Sócrates, isto é, o de perguntar, deixando o filósofo na posição curiosa e nova de respondente. Posição incômoda ao filósofo que, após sete perguntas, não resiste. Agoniado, pede um favor a Polo e passa a direcionar as perguntas a que se vê submetido.

“Sócrates: Pergunta-me então que espécie de arte é para mim a cozinha.

Polo: Está bem: que espécie de arte é a cozinha?

Sócrates: Não é arte nenhuma, Polo. Pergunta-me agora: 'O que é então?'

Polo: Seja essa a pergunta.

Sócrates: Uma forma de atividade empírica. Pergunta-me ainda: 'Destinada a quê?

Polo: Admitamos que faço essa pergunta.

Sócrates: A produzir agrado e prazer, Polo” (462d-e).

Ora, o que o incômodo de Sócrates produz é que o raciocínio filosófico se estabeleça de forma logicamente encadeada a partir de uma definição. Curioso que Sócrates não se aguenta no papel de “aluno” de Polo. Não aguenta um direcionamento que não seja para o estabelecimento da filosofia, da sua filosofia. Ainda que possamos ver nessa recusa de Sócrates do papel de aluno, uma recusa a um certo enredamento a que o "professor" Polo destinara o seu perguntar, parece-me curioso justamente que fora do método, a filosofia socrática não resiste. Sem que se defina antes não é possível conversar, eis o primeiro princípio aqui do método. Ora, se para conversarmos com o outro da filosofia este precisa entrar dentro de um método de conversar, próprio da filosofia, então não é possível 
simplesmente conversar sem que antes não haja um certo ensino do método. Cabe à filosofia, portanto, sempre estar em papel de comando na relação com o seu outro, pois do contrário não haverá diálogo possível, o outro somente ao acaso poderia entrar dentro do círculo do filosofar. É justamente isso que o incômodo socrático demonstra. Bom, se é necessário um ensino do método antes que se propriamente filosofe, resta saber como se dá esse ensino. Sócrates insinua neste diálogo que se há um trabalho de convencimento inicial, esse trabalho é da ordem do um para um e, não mais como a retórica tradicional, do um para uma multidão.

"Pela minha parte, não sei apresentar mais do que uma testemunha do que afirmo, aquele mesmo com quem estou a dialogar; quanto aos outros desejo que tenham muita saúde; só sei pedir o voto a um, com a multidão não sei conversar”. (474b)

Ora, resta saber ainda como se dá esse trabalho de convencimento um a um. Talvez o próprio desenrolar do diálogo já seja esse trabalho de convencimento, ao aprendizado do método só se chegaria ao final. Antes de estabelecermos isso, no entanto, um ponto chama a atenção nessa distinção socrática de que o ensino da filosofia se faz a partir da relação entre um professor e um aluno: o porquê de a filosofia não poder ensinar a muitos. Por que o ensino de filosofia necessita de uma forma de argumentar mediante perguntas e respostas que exigem um trabalho muito próximo entre quem pergunta e quem responde? Como sustentar assim, hoje, um ensino de filosofia para 35-40 alunos? Em que medida é possível ensinar filosofia a essa multidão? Ou deveríamos pensar num ensino não à maneira socrática, mas à maneira de outro filósofo, ou quem sabe até, à maneira retórica, haja vista a tradição de falar a multidões? Mas ainda que seja possível outras entradas talvez mais coerentes com o ensino atual, como não sustentar, com Sócrates, que o ensino de filosofia passa por essa relação próxima de "se não conseguir obter de ti, e só de ti, um testemunho favorável aos meus pontos de vista, entendo que não cheguei a nenhum resultado positivo em relação ao tema da nossa discussão” (472b-c)? Ou seja, como sair da encruzilhada de ter, por um lado, uma estrutura de ensino pensada para multidões e por outro, uma necessidade própria da filosofia de proximidade para que sejam possíveis convencimentos e transformações dos sujeitos que dela participem?

Cabe aqui, no entanto, uma ressalva. Se Sócrates adverte Polo de que a filosofia não sabe conversar com muitos e de que o processo se dá na forma de um para um, isso em certa medida é contradito pelo próprio desenrolar do diálogo, pois além da relação direta com o seu interlocutor, há uma certa “provocação” no que está sendo discutido para que atue sobre os demais presentes. Assim, não parece que Sócrates esteja somente interessado ao conversar 
com Polo, em Polo, mas também em Górgias, em Cálicles e em todos ali presentes, mesmo os que não aparecem para falar. Além disso, relembrando que Polo entra no diálogo para corrigir o passo em falso de seu mestre, a contradição, e se sai convencido ao final dos argumentos socráticos, logo não é só Polo que é convencido, mas também Górgias e todos aqueles que, num primeiro momento, estariam suscetíveis ao seu discurso. Platão eleva esse ensino, no entanto, muito além do um a um pensado por Sócrates, tornando o ensinamento a Polo e a Górgias um ensinamento à multidão que o leu. Logo poderíamos pensar também que, para além da relação um para um da experiência filosófica, há a relação com os ouvintes provocados e, ainda, a relação com a multidão de leitores de uma determinada filosofia. Com o quê, a diferença levantada por Sócrates entre o convencimento de um e o convencimento de muitos, entre filosofia e retórica, portanto, perde um pouco sua força. Se Sócrates não falava à multidão, por uma exigência de método e não por falta de vontade de convencê-los, a escrita platônica fala. Foi a história que fez com que as experiências circunscritas de Sócrates se tornassem fala para multidões. Resta à filosofia saber se essa sua história fala como Sócrates falava, ou seja, resta saber se a filosofia ao ser escrita e pensada para multidões, guarda ainda semelhanças com o testemunho e com as exigências de convencimento de que Sócrates nos fala com o seu ensino.

Se a filosofia socrática se contradiz, ao ser escrita por Platão, ou se o próprio Sócrates se contradiz ao praticar algo que diz não poder, o convencimento de muitos, é algo que ainda precisaríamos distinguir. No entanto, há uma contradição em que o próprio Sócrates se vê imerso no Górgias, que se refere ao modo de dizer. O filósofo, impaciente na posição de aluno de Polo, cai em contradição ao fazer aquilo que critica no outro: discursos longos. E o faz porque na posição de aluno não consegue colocar algumas ideias-chaves para o estabelecimento de um pensamento. Polo não consegue fazer com que Sócrates paira suas ideias. Logo, torna-se eminente uma mudança na forma do discurso. Assim, o maior discurso do diálogo é, paradoxalmente, de Sócrates. Não é isso também contradição? Ou a contradição só se dá no plano de ideias opostas? Contradição é contradicção? Dicção no sentido do que é dito ou no sentido da forma em que é dito? Concepções diferentes de linguagem, talvez, entre sofística e filosofia e, assim, concepções diferentes também de contradição. Cabe à filosofia, no entanto, mudar a maneira do seu discurso se as perguntas do seu interlocutor não levam ao estabelecimento de um pensamento que quer nascer? Perguntas indigestas e problemáticas a quem queira ver em Sócrates e em Platão apenas o que recomendam como método: maiêutica e dialética. O que significam esses termos na fluidez de um diálogo filosófico, nas circunstâncias de um encontro da filosofia com o seu outro, seus interlocutores? No entanto, 
ainda que se use um discurso que condena, os discursos longos, próprios muito mais da retórica do que da filosofia, ao menos vale a consciência sempre atenta do filósofo que gentilmente pede desculpas frente à contradição.

"Foi talvez um procedimento estranho o meu, de te proibir os longos discursos para depois me espraiar tão longamente, mas tenho para isto uma desculpa: enquanto te falei concisamente, não me entendeste bem nem foste capaz de aproveitar nada das respostas que te dei; estavas sempre a pedir explicações.” (465e)

Um mea culpa é o que faz Sócrates. Sempre falho, porém, à medida que a contradição já está cumprida. Sequer a desculpa parece convincente. Ora, se a prolixidade de Sócrates se deve a uma necessidade de compreensão pedagógica, o mesmo não poderia acontecer com Polo? Discursos mais longos também não poderiam ter ajudado Polo na sua explicação? E pior, Sócrates, ao perguntar, também não está “sempre a pedir explicações”? Quando é o momento em que a desculpa pedagógica vale? Vale somente para aquele que detém o comando do diálogo, dos seus tempos? O mea culpa, assim, parece não passar de um recurso de poder. Polo não pode sequer usar da mea culpa, pois ao aceitar fazer discursos curtos aceitou também ser tolhido nas suas possibilidades de argumentação, na sua potência de orador. Aceitar ser “dirigido” por Sócrates, aceitá-lo como professor, é nesse caso aceitar de início que se pode menos. A mea culpa, entretanto, se é um recurso de poder, à medida que só o filósofo pode usá-lo, pois é ele quem pede discursos curtos, é um recurso que, nesse contexto, é um sinal muito mais de fraqueza do que de força, pois não abole a contradição. E se é a contradição justamente o ápice do ensino de Sócrates, uma vez que a partir daí o sujeito percebe que ignora o que achava saber, por que isso não acontece com o próprio Sócrates? Por que o filósofo não percebe que ignora o que seja um bom método para conversar? Por que se justifica, colocando na responsabilidade de Polo, na sua falta de compreensão, o motivo da contradição? Ideias contraditas levam à ignorância e à filosofia, mas posturas contraditas não? Que diferença há entre passar incólume à contradição, como faz Górgias, e fazer um mea culpa ao final dela, como Sócrates? Ambos não se contradizem e continuam vivendo? Sequer a polida oferta de Sócrates a Polo parece convincente. Oferecer esse recurso quando praticamente toda a sua teoria está estabelecida parece pouco inspirador. O que Polo poderia fazer alargando seus discursos com o debate praticamente encerrado? Oferecer ferramentas ao final do jogo nunca é o mesmo que oferecê-las de início, o que nos remete à relação entre argumento e momento de discurso. A oferta de Sócrates, nesse sentido, 
é uma oferta retórica, à medida que demonstra certa solidariedade ao outro na certeza e na segurança de que ele não poderá fazer praticamente nada com aquilo, o que costumamos chamar no Brasil de “jogar para a torcida”.

\section{Cálicles: o aluno hostil}

Diante da ironia que derrota Polo, em que Sócrates mostra que fazer o mal a quem erra é fazer que escape a condenações, Cálicles não resiste a tomar parte no diálogo perguntando: “Diz-me, Querefonte, Sócrates está a falar sério ou está a brincar?” (481b) A relação de ensino filosófica de um para um ganha, assim, um terceiro. Ainda que num grupo esteja sendo trabalhado um aluno, suas perguntas, isso não implica que aqueles que estiverem ouvindo não se sintam chamados a participar do diálogo quando este lhe afetar. O que Cálicles mostra é que, sendo a fala filosófica provocativa, ao menos a de Sócrates o era, há sempre a possibilidade de ter a filosofia mais de um interlocutor, ao menos indiretamente. Mas não apenas isso, Cálicles é um interlocutor diferente, vem ao encontro do discurso filosófico pela via da indignação e questiona a relação da filosofia com seus interlocutores, se é uma relação de lealdade ou não.

“Sócrates, fiquei com a impressão de que falaste com a vivacidade e a juvenil irreflexão de um autêntico orador político, e a razão de toda essa eloquência está em que Polo foi vítima do mesmo percalço que censurara a Górgias, a propósito da conversa que este travou contigo. Efetivamente, Polo disse que, ao perguntares a Górgias se ensinaria a justiça a quem se apresentasse em sua casa, sem conhecimento desta matéria, para receber lições de retórica, Górgias, por vergonha e em obediência aos hábitos estabelecidos, sabendo que escandalizaria se reagisse de outro modo, respondeu que sim; tinha sido esta afirmação que o pusera em contradição consigo próprio, coisa que tu muito apreciaste. Nesta altura, Polo riu-se de ti, a meu ver com toda razão. Mas agora ei-lo na mesma situação de Górgias, e o que me desagrada na sua atitude é que ele te tenha concedido que cometer a injustiça é mais feio que sofrê-la. Com esta concessão deixou-se enredar nos teus discursos e acabou por não saber que dizer, tudo porque se envergonhou de exprimir o seu pensamento. E é assim que tu, Sócrates, dizendo que buscas a verdade, orientas na realidade os teus discursos para estas vulgaridades de tribuna, os teus princípios que não são belos por natureza, mas apenas por convenção. [...] se alguém, por vergonha, não ousa dizer o que pensa, acaba necessariamente por cair em contradição. (482c-483a) 
Cálicles é assim o mais hostil e mais contundente em suas críticas à filosofia. Não entraremos aqui, novamente, no mérito de seus argumentos, mas na relação que Sócrates e a filosofia estabelecem com ele diante de tamanhas críticas. O diálogo entre o filósofo e seu aluno, agora hostil, passa por uma relação de concessões, elogios, mas também assume uma forma mais violenta. A sua ironia característica assume agora tons mais sarcásticos.

"Ocorre-me, com efeito, que, para poder verificar com segurança se uma alma vive bem ou não, é preciso possuir três qualidades que tu reúnes: saber, benevolência e franqueza. [...] Górgias e Polo são ambos sábios e meus amigos, mas falta-lhes a franqueza, porque são mais tímidos do que convém. A prova disto? A sua timidez é tão grande que chegam ao extremo de, por vergonha, se contradizerem na presença de muitas pessoas, em relação a assuntos que são da maior importância. Tu, pelo contrário, tens tudo aquilo que aos outros falta: és um homem bastante instruído, como o poderá testemunhar a maior parte dos atenienses e, és além disso, meu amigo. Como o sei? [...] Ao ouvir-te agora aconselhar-me do mesmo modo que aos teus íntimos amigos [a saber, a não praticar a filosofia quando adulto], vejo nisso uma prova cabal de que me tens verdadeira amizade.” (487a-d)

Surge nesse elogio a Cálicles alguns pontos que merecem ser destacados. Em primeiro lugar, não deixa de ser um recurso retórico elogiar seu interlocutor para que o mesmo se sinta à vontade para falar. Mas nisso também entra o que seria um segundo ponto, que é propriamente a questão da amizade. O aspecto fundamental da interlocução é a amizade, ou seja, para que haja comunicação é preciso que eu veja na fala do outro algum interesse que me disponibilize a falar também. Amizade aqui não está sendo pensada, e a relação entre Sócrates e Cálicles mostra muito bem, como disposição para as mesmas coisas, como consenso. Pode haver amizade no dissenso e, até mesmo, em demonstrações de hostilidade. Assim, se a amizade é necessária à interlocução com a filosofia, o inimigo da filosofia não é necessariamente o aluno explicitamente hostil, esse pode ser um amigo e um grande interlocutor, o inimigo é aquele para o qual o discurso da filosofia sequer o disponibiliza a falar, a pensar, sequer o afeta.

Cálicles, ao contrário, mantém o diálogo vivo, a cada hostilidade apresentada. As farpas sobressaltam-se mutuamente, um lançando-as na direção do outro. Cálicles explicitamente, Sócrates implícita e ironicamente, como no caso em que Cálicles se irrita com as constantes analogias à culinária e à medicina. 
“Cálicles: Não sabes falar senão de comidas, bebidas, médicos e outras tolices do mesmo gênero! Não era disso que eu estava a tratar.

Sócrates: Mas, afinal, consideras ou não que o melhor é o mais sábio?

Cálicles; Considero.

Sócrates: E não dizes que o melhor deve ter mais do que os outros?

Cálicles: Não me referia a comidas ou bebidas.

Sócrates: Percebo, querias talvez falar de vestuário.” (490d)

A comédia instalada pelo professor Sócrates diante do hostil aluno Cálicles, ao invés de paralisar o diálogo, torna-o vivo, pois a irritação de Cálicles só o faz ir adiante, numa aparente representação do bufão grotesco, sempre pronto a retrucar, e do bobo da corte, Sócrates, sempre pronto a usar de um truque.

Diante de novas investidas dialéticas, tentando por meio de perguntas e respostas chegar a definições mais precisas e estáveis, mas que resultam sem sucesso, Sócrates se vê na necessidade de lançar mão mais uma vez de outros usos da linguagem para ensinar. Conta um mito sobre as partes da alma para tentar convencer seu interlocutor a mudar de opinião, a aceitar que os moderados são mais felizes que os intemperantes e, ao final, ciente das dificuldades de usar recursos "impróprios” ao discurso filosófico, ao menos lhe explica a necessidade pedagógica de tal recurso.

"Esta linguagem é, sem dúvida, um pouco bizarra, mas traduz bem as ideias que eu gostaria de te comunicar, se fosse capaz, convencendo-te a mudar de opinião e a preferir uma vida regrada, que se satisfaz com o que tem e não deseja mais, a uma vida insaciável e dissoluta”. (493c)

Cálicles, porém, não se sensibiliza com o modo desse Sócrates-poeta falar e continua resoluto em suas convicções. O professor-poeta, no entanto, não desiste de seu aluno e passa à apresentação de uma “outra imagem”, fruto de sua criação. A imagem apresenta o homem moderado como o proprietário de tonéis em bom estado e o intemperante como o proprietário de tonéis em mal estado. O primeiro, uma vez enchidos os seus tonéis, viveria em paz. $\mathrm{O}$ segundo, por conta de vazamentos e problemas, passaria dias e noites a tentar encher os seus tonéis para conseguir alguma coisa. Cálicles entende a imagem, mas diz preferir o prazer que sente aquele que na instabilidade dos seus tonéis vive. Sócrates, já um pouco irritado diante 
de tantas negativas de seu aluno, investe-se de coragem e passa a questionar Cálicles em cima ainda da imagem do prazer. Passa a falar de sarna e comichão e pergunta se o prazer estaria em "levar a vida a satisfazer esse desejo” (494c). Cálicles não pode deixar de ver nessa investida em palavras fortes “um orador popular de grande categoria!” (494d), o que Sócrates não nega. Imbuído ainda de certa ira pede, no entanto, a Cálicles que continue a respondê-lo. Suas respostas, porém, o levarão de encontro a uma primeira versão do princípio de nãocontradição de Aristóteles, já aqui formulado.

“Sócrates: Dizes afinal que uma pessoa sente dor e prazer ao mesmo tempo, no caso de beber quando tem sede. Não é verdade que os dois efeitos concorrem ao mesmo tempo no mesmo lugar, seja no corpo ou na alma, à tua escolha, porque eu não faço questão disso?

Cálicles: É assim.

Sócrates: Mas tu dizes que não é possível ser feliz e infeliz ao mesmo tempo.

Cálicles: Digo-o, de fato.

Sócrates: Acabas, no entanto, de reconhecer que se pode sentir dor e prazer simultaneamente.

Cálicles: Parece que sim.

Sócrates: Então é porque o prazer não é a felicidade, nem a dor a infelicidade, de modo que o agradável resulta distinto do bem.” (496e-497a)

Sócrates lança mão agora da lógica, de um "silogismo” para de uma vez por todas convencer Cálicles. Diante do enredamento no princípio não há saída a não ser admitir as distinções que faz o filósofo. Cálicles, no entanto, mantém-se firme, como um aluno teimoso, a dizer explicitamente que não entende que rumos são esses que estão sendo tomados.

“Cálicles: Não percebo nada dos teus sofismas, Sócrates.

Sócrates: Percebes, sim, finges é que não percebes, Cálicles.” (497a-b)

Que fingimento é esse que Sócrates vê em Cálicles? Usar de argumentos lógicos é sempre sinônimo de convencimento? Em que medida é possível duvidar da lógica ou em que medida é possível não compreendê-la? O que significa esse fingir para o ensino? Então não basta a apresentação de uma argumentação lógica para que o outro se convença, para que saia modificado da relação pedagógica? O que ainda é preciso para que o ensino de filosofia seja possível? Novamente é a amizade que volta à tona. Cálicles engana Sócrates ao ser levado a sério pelo filósofo. À certa altura faz troça, diz que à medida que concorda com o filósofo, 
para se divertir, e lhe faz a mínima concessão, isso é tomado como verdade, o que para Cálicles, ao viver essa situação com Sócrates, não passa de uma relação infantil do filósofo que, na ingenuidade toma as suas palavras como verdade. Essa relação da filosofia com a infância merece todo um olhar especial, o que aqui inspira ao menos um sentido na relação da filosofia com o outro. Levamos a sério o que as pessoas nos dizem, acreditamos nas suas palavras e, como crianças, talvez nos iludamos com esse mundo contado, com esse mundo pintado pelas palavras. No fundo, as palavras não passam de mera fantasia. Então resta perguntar o que fazer com essas palavras que os outros nos dirigem e que podem não ser verdadeiras, autênticas, no sentido de que os sujeitos podem se desresponsabilizar por elas?

Sócrates nos diz que não temos “outro remédio senão tirar o maior partido das circunstâncias, como se costuma dizer, aceitando o que me dás” (499c). Ou seja, só nos resta trabalhar com o que nos é oferecido, seja isso verdade ou brincadeira. E não adianta acordos com nossos interlocutores. Ao início da discussão com Cálicles, Sócrates, pensando se tratar de um amigo, pede que acordem quanto à verdade das colocações e dos procedimentos a se seguir.

“Há uma coisa que convém desde já que fique assente: sempre que concordares comigo em relação a um ponto da nossa discussão, considerá-lo-emos suficientemente provado e não teremos de o submeter a novo exame. É evidente que não me darás a tua concordância por falta de saber ou excesso de timidez, nem quererás, com isso, enganar-me, visto que és meu amigo, como tu próprio declaraste. O nosso acordo significará, portanto, que atingimos realmente a verdade.” (487e)

Agora, diante de seu aluno hostil e zombeteiro, Sócrates sabe que não se trata de um amigo, de alguém que queira conversar, mas simplesmente de alguém que quer fazer uso da palavra para apenas se divertir. Sócrates continua, no entanto, sua aula como se nada tivesse acontecido, não mudando em nada os procedimentos, o método. Faz as vezes da circunstância, trabalhando com o que é possível. Ora, como pensar essa continuidade? Por que continuar ensinando se nosso aluno faz pouco ouvido? Sócrates tem no mais alto grau o seu saber e, por isso, passa por cima de todas as circunstâncias porque acredita no que ensina, acha que a filosofia interessa a qualquer pessoa. Mas estaríamos nós também tão certos disto diante de alunos tão hostis como Cálicles? Serve-nos as palavras de Sócrates? É uma questão de fé seguir ensinando em condições tão pouco amigáveis? Fiquemos, ao menos com as palavras do filósofo e, quiçá, com a dúvida. 
“Em nome do deus da amizade, Cálicles, deixa-te de brincar comigo e de me responder o que te vem à cabeça contra as tuas próprias convicções; não interpretes tão-pouco as minhas palavras como uma simples brincadeira. Vês que a nossa conversa tem por tema um assunto capaz de interessar a qualquer pessoa, por pouco juízo que tenha. Haverá, efetivamente, coisa mais importante do que saber qual o gênero de vida que convém adotar: se aquele para que me convidas, o de agir como um homem, falando ao povo, praticando a retórica, exercendo a política da maneira que vós hoje a exerceis, ou o outro que eu recomendo, o cultivo da filosofia? Do confronto de ambos ressaltará a sua diferença e talvez o melhor seja precisamente começar por distingui-los, como eu há pouco tentei fazer. Uma vez de acordo sobre o fato de que estes dois gêneros de vida são realmente distintos, poderemos examinar em que consiste a diferença e escolher o melhor.” (500c-d)

Talvez caiba ainda perguntar, diante de tamanha certeza: Onde está essa "qualquer pessoa” que necessariamente se interessa por filosofia? Quem é esse “todos” que escapa à totalidade dos interlocutores, uma vez que existindo um Cálicles esse "todos” passa a indicar muito mais uma "vontade de totalidade”, própria aos universalismos da filosofia, do que à soma dos sujeitos reais com os quais nos deparamos? Isso também não significa que a filosofia não interessa a ninguém, obviamente. O que está em jogo, talvez, é essa crença da totalidade, de que a todos os seres racionais, pensantes, a filosofia seria algo a lhes interessar. Não entrando aqui no mérito desta polêmica, parece-me, ao menos, que desde a filosofia é preciso pensar o que é Cálicles? Ou seja, o que é aquele que não participa desse "qualquer pessoa interessada”? Seria muito fácil falar aqui em exclusão, em um sujeito excluído, mas a questão parece mais difusa à medida que Sócrates tenta a todo momento "incluir” Cálicles no diálogo com a filosofia. Como então pensar essa relação que surge a partir da relação com uma constante resistência e hostilidade frente à filosofia? Seguir adiante, como se o "qualquer pessoa” pudesse invadir nossa sala em algum momento, na esperança de que a redenção do ser racional possa salvar a hostilidade de nossos alunos?

Se o filósofo e o professor de filosofia prosseguem até a exaustão com a fé no interesse pela filosofia, é o aluno aqui que corta a relação, que provoca a morte da ainda restante e esperançosa aula. É ele quem, não vendo mais sentido sequer na troça, não aguenta e desiste. Cálicles explicitamente diz, na tentativa de estabelecer um ponto final à aula: "Não me interessa nada daquilo que estás a dizer; se te respondi foi só para dar prazer a Górgias” (505c). Sócrates se vê, assim, sem saber o que fazer. Como é possível uma aula em que é o 
aluno que define o seu final? O que fazer com o que ainda precisa ser dito, com o que ainda precisa ser ensinado e pode interessar a “qualquer pessoa”? Diante da negativa de um interlocutor, que seria a melhor opção para o professor Sócrates, este se vê forçado a “monologar”. Mas como seu monólogo é sempre um diálogo, “o papel de dois homens” (505e), Sócrates pede que lhe interrompam com objeções "se algum de vós achar que admito a mim próprio como verdadeiras coisas que não o são” (506a) .

O incansável professor, frente às contribuições ainda que precárias de Cálicles, "Fala, meu caro, e acaba” (506b), “Continua, caro amigo” (507a), reavive esse no diálogo por meio de novas investidas sobre falas sensíveis ao orador como: “Acho que é necessário ocupar, na cidade, um lugar de direção ou mesmo exercer a tirania, ou pelo menos ser do partido dos que governam” (510a). Diante desse flerte socrático Cálicles cai novamente na rede do filósofo e o diálogo ganha um último suspiro. Reavivar um morto, no entanto, não é senão estar morto ainda em vida, ou seja, o diálogo prossegue muito à maneira como até então procedera, com respostas mais efusivas de Cálicles quando o argumento socrático passa próximo às suas opiniões e com troças como “Queres que eu concorde contigo?” (516c), quando lhe parece absurdo. Pouca vida habita esse final. Parece realmente o último suspiro de um morto, morto decretado pelo aluno Cálicles ao desistir do diálogo. Sócrates continua a fala, mas não fala mais só a Cálicles. Este é um vulto, um vulto de aluno sobre o qual voam as palavras do professor Sócrates, agora muito mais um professor-orador. Diante desse vulto, Sócrates expõe suas ideias, quase num formato de aula expositiva, concluindo sua eminente e interessante tarefa com uma síntese das discussões.

"Das nossas longas discussões saíram refutadas todas as teorias, menos uma, que permanece firme: a de que convém evitar com mais empenho cometer a injustiça do que sofrê-la; que cada homem se deve esforçar mais por ser do que por parecer bom, em público como em privado; que, se alguém mal em alguma coisa, deve ser castigado, porque o maior bem, depois de ser justo, é passar a sê-lo, sofrendo o castigo que se mereceu; que é preciso fugir de toda a forma de lisonja, tanto em relação a si próprio como em relação aos outros, quer sejam poucos, quer sejam muitos; finalmente que se deve pôr a retórica, como qualquer outra coisa, sempre à serviço do bem” (527b-c).

Concluído os ensinamentos da aula, o professor convoca seus alunos a agir. O professor-orador Sócrates exorta seu aluno final, o ainda Cálicles, a seguir um caminho diferente do que vem seguindo: 
“Tomemos, por isso, como guia a narrativa de há pouco, que nos mostra que o melhor caminho a seguir é o exercício da justiça e das outras virtudes, na vida como na morte. Escutemos o seu apelo e convidamos os outros a proceder como nós, porque esses princípios em que acreditas e em nome dos quais me exortas são, realmente, sem valor, Cálicles”. (527e)

Sócrates, enfim, consegue terminar e mostrar o que seria de interesse a "qualquer pessoa”. Podemos discordar do caminho escolhido por Sócrates. O que nos interessa aqui, desde o início, é apenas ver o caminho e as escolhas na forma de dialogar que o filósofo apresenta a cada momento, a cada investida, solidária ou hostil ao seu ensino. Interessa pensar a relação da filosofia com esses outros, o que esse outro provoca ao ensino da filosofia. Sócrates e seus interlocutores parecem ser um bom exemplo de como pensar essa relação. Se a aproximação de Górgias, Polo e Cálicles com algumas figuras que podemos identificar em sala de aula são desmesuradas, à medida que esses personagens são oradores adultos, investidos de compreensões diversas sobre linguagem, sobre filosofia, etc., a relação que travam com a filosofia e com a figura "professoral” de Sócrates parece em muitos momentos emblemáticas e elucidativas de problemas que, em alguma medida enfrentamos em nossas salas de aula. Não somos Sócrates nem nossos alunos são Górgias, Polo ou Cálicles, mas nos revestirmos desses personagens talvez nos ajude a pensar as nossas práticas. A cena pintada por Platão talvez nos sirva como um quadro para onde olhamos na esperança de, na riqueza dos detalhes, podermos ver algo que não víamos, a pensar questões que até então não se afiguravam. O Górgias é, no entanto, muito mais que o esboço desse quadro que tentamos aqui. Fica o convite para olharmos para a filosofia na busca por elementos de seu ensino. Nem tanto conteúdos, mas formas de ensinar.

\section{Referências}

NAILS, D. The people of Plato - A prosography of Plato and other socratics. Indianopolis: Hackett Publishing Company, 2002.

PLATÃO. Górgias. Lisboa: Edições 70, 2006

PLATÃO. Diálogos - Mênon, Banquete, Fedro. Porto Alegre: Ed. Globo, 1960.

i Mestrando do Programa de Pós-graduação em Educação da Universidade do Estado do Rio de Janeiro (PROPED/UERJ). Correio eletrônico: viniciusvicenzi@gmail.com 